\title{
TWO LITTLE RED SHOES IN NO-MAN'S-LAND
}

Hertzog Biermann*

It was reported from Rome on 18 July this year that Major Walter Reder, last of the important Nazi war criminals in Italian custody, was to be allowed a degree of supervised freedom after serving 28 years of a life sentence. An Italian military tribunal declared that Reder repented his acts.

Whether Reder can be said to have paid the full penalty for the brutal massacre by SS troops under his command of more than 1800 Italian farm folk in the mountain lands near Bologna at the end of September 1944, is a moot point. Those of us who witnessed some of his handiwork when out on patrol in no-man's-land in the winter of 1944-45, would have wanted to see him hanged, drawn and quartered. But we had no means of knowing then who Reder was or how many more people than we came across, his 'Death's Head' battalion of Nazi stormtroopers had butchered.

Reder was tried by an Italian court in 1950 for war crimes and sentenced to life imprisonment. We were all back in South Africa then and I cannot recall reading any newspaper reports about Reder's trial.

It was not until a book 'Silence on Monte Sole', published in 1968 and written by LieutenantColonel Jack Olsen, a wartime officer in the U.S. 5th Army, came into my hands some years ago, that I was able to bring into perspective the gruesome picture of what had happened when virtually the entire community of farmers and villagers were wiped out over an area of possibly 20 square kilometres bounded on the West and East by the Reno and Setta Rivers in the Apennines. It stretched South to North from Monte Salvaro to the town of Marzabotto beyond Monte Caprara and Eastwards across Monte Sole down to the Setta River.

Major Reder commanded a battalion of SS troops which was assigned to the job of liquidating the Partisan groups of Italian guerilla fighters behind the German lines in this area. A Partisan group named Red Star operated in the Monte Sole region. Because of the name Red Star the members of this Brigade were presumed to be heavily Communist-orientated, which they prob- ably were on account of the persecution suffered by individuals at the hands of Mussolini's Blackshirt Fascists before the Nazi 'Death Head's' battalion moved in.

It was in reprisal for the Brigade's harassment and acts of sabotage behind the German lines that Field Marshal Kesselring, Commander-in-Chief of the German Army of the South, issued an order, duly executed by Major Reder, to 'obliterate Monte Sole from the face of the earth.' As a result, every man, woman and child in the environs of Monte Sole, was done to death in an orgy of barbarous brutality that lasted from 29 September to 2 October 1944.

I do not know if Reder's battalion formed part of the 16th SS Hermann Goering Reichührer Division. It was this Division with which the 6th South African Armoured Division became embroiled - as part of the U.S. 5th Army under General Mark W. Clark from September 1944 to the end of the Italian campaign in May 1945 - in gory battles during the South Africans' advance from Florence to Bologna across the Apennine barrier. But Reder's battalion did operate directly behind the line of retreat of the 16th SS Division before the latter was finally routed by the Springboks at the battle of Monte Salvaro or Point 826 on 23 October 1944.

During the six months of static warfare which followed, when the South Africans occupied their Winter Line between the Reno and Setta Rivers in the Apennine mountain fastness, patrols sent into the snowbound no-man's-land between Monte Salvaro and Monte Sole where the Germans were dug in, began to discover what Reder and his battalion of butchers had been up to before we arrived on the scene. But the troops at the front as I noted earlier, had no means of knowing at the time on what an enormous scale the horrors of which they became aware piece-meal, had been perpetrated.

There was a hamlet named Casa Creda at the foot of Monte Salvaro near the River Reno to which I accompanied Major Lionel Gallimore, M. C., commanding ' $\mathrm{B}$ ' Company of the Royal Natal Carbineers, on a night patrol late in December 
1944. There he showed me the barn in the farmyard where his men had previously discovered 80 bodies of men, women and children who had been slaughtered in a mass execution.

In the light of a pale moon, I saw lying on the threshold of the only door to the barn, the frozen body of a year-old baby and in the gloom beyond, a pile of fire-charred corpses of the others who had been mown down by machine-gun fire. Their executioners had subsequently attempted unsuccessfully, to burn down the barn and cremate the victims.

We were not to know then that this was not an isolated incident occasioned perhaps by the frustration and fury of the routed SS Division when they were retreating from the peak of Monte Salvaro directly above Casa Creda.

About two months before my visit to Casa Creda, another incident occurred on a cold and misty morning at the beginning of November which, again unknown to those of us who witnessed it, formed another link in the chain of events comprising that gruesome episode.

The Royal Natal Carbineers had relieved the 1st Scots Guards on Monte Termine a few days earlier. Company headquarters were located in a shell-battered farmhouse on top of the mountain on the edge of no-man's-land. Half-way down the slope below the farmhouse, was the hamlet of Termine where Captain 'Koffie' Reznek, M. C., the Carbineers' medical officer, had set up his Regimental Aid Post. I had spent the night there and early in the morning as we stood around drinking coffee, we were suddenly taken aback by the sight of a procession of what looked like human scare-crows descending the muddy cart track down the side of the mountain. There were about 50 or 60 of them and they straggled into view from around a bend in the track which led straight into the heart of no-man's-land beyond Monte Termine.

It is obvious now that they were survivors of the great massacre a month before of the inhabitants of the score of mountain farms, hamlets and villages between the front lines. In the wake of the German retreat to Monte Caprara and Monte Sole on the far side of the area laid waste by Reder and his SS butchers, these pathetic refugees had emerged from their hiding places in the woods and ravines to seek sanctuary in the Allied lines.

There wasn't time to ask questions because we knew that punctually at 8.30 , the German guns beyond the Reno River would deliver their early-morning load of shells on Termine as they had done every day since the Regimental Aid Post moved in there. At the far end of the hamlet a company of the Royal Durban Light Infantry was dug in with their mortars and Vickers machineguns and they, rather than the Carbineer medics, were the target of the German gunners.

'Koffie' and his men, including a detachment of Cape Coloured stretcher bearers, gave what aid and comfort they could to the assortment of old men and women, younger women, boys and girls and babes-in-arms. They were all shivering in the cold, wet morning air, hungry and utterly miserable.

They were given coffee and bread and were pathetically grateful to find themselves safe at last and cared for by the 'Americans' they assumed us to be, since our Division was part of the U.S. 5th Army. As quickly as possible they were loaded onto ambulance jeeps and whatever other transport was available and sent down the line to 12th Brigade headquarters near Grizzana. That was the last we saw or heard of them.

About half-way between the front line on the crest of Monte Termine and the German-held village of San Martino in the valley below Monte Caprara and Monte Sole, the Carbineers maintained an outpost on a hillock named Point 512, astride the track that ran the length of no-man's-land. It was occupied by a 24-hour standing patrol of platoon strength and one could only get there and back to the company headquarters on Monte Termine by night. I spent a night and a day at Point 512 early in January, 1945.

It was a rather hectic night during which a German patrol approached the outpost and was beaten off with the aid of artillery fire, except that we ourselves were nearly written off by our own guns when the first salvo of 5.5. shells fell short and all but buried some of us under a load of slush and snow.

The day dawned quiet and peaceful. At about nine o'clock the company commander came through on the field telephone and suggested that I take two men to do a patrol into an area where our map showed a farmstead named Pornera to be located.

It was possible that the name Pornera was a corruption of the name Prunaro, since I found no mention in Olsen's book of Pornera, but he does 
refer to Prunaro and also to Prunaro di Sopra, which I believe might well be the place I went to that morning. There was another farm in the area with homesteads about two kilometres apart, named respectively Vallegio di Sotto (the lower one) and Vallegio di Sopra (the upper one). I also led a patrol to the latter place that afternoon, but that's another story.

The company commander back at Monte Termine said: 'You might look around for tracks of German patrols and signs of any unusual activity around there.'

I set off for Pornera as we knew it, accompanied by Privates 'Cowboy' Lawrence and Bill Coetzee. Clad in snow suits, we felt reasonably safe from observation by the Germans on Monte Sole. The sun shone on the white expanse of snow around us and we covered about a kilometre before we came upon the hamlet comprising about a dozen buildings ranged around an open farmyard. The silence was eerie and there was a sinister atmosphere of lifelessness about the place.

Then one became aware of the sour-sweet stench of death. in the still air. All the farm buildings showed signs of having been set on fire with charred wooden beams sticking out from beneath broken tile roofs, but the damage seemed mostly to have been caused possibly by hand grenades thrown into the buildings to destroy the interiors.

As we came into the farmyard proper, we saw two snow-covered mounds which, when we scratched the snow from them, turned out to be the carcases of large pigs, partially decayed but frozen stiff.

One of my companions exclaimed suddenly: 'Look, there's a row of bodies over there,' and he pointed to a spot some distance away. We came upon 15 snow-covered mounds neatly lined up next to what was obviously a water furrow and found these to be bullet-riddled bodies, mostly of women, some teen-age boys and a few old men.

About 50 metres away lay the lone body of a lad who had apparently bolted and was shot down as he ran. There was an obvious connection between the massacre here and what I had seen that night back at Casa Creda a week or so before.

I made a rough sketch of the locality and noted where the bodies were lying before we turned to go back to the outpost. We would be spotted sooner or later if we hung around too long and I felt it was time to go. But walking back through the farmyard, I looked again at the main farmhouse and decided we should at least try to see what was left inside. The building was badly battered but one wing seemed still to be intact except that the doorway was blocked by heavy beams from the shattered roof above.

Lawrence, Coetzee and I wrested the beams out of the way and I pushed open the door, telling them to keep an eye open outside for anything untoward. The odour of death was all-pervasive as I stepped into the room. In the centre stood a large table on which were plates of half-eaten food. In the middle of the table was a soup tureen with the - ladle standing straight up in the very centre, held in position by the frozen contents.

But my eyes were drawn simultaneously to a splash of colour beyond the table, above the fireplace in the wall. On the mantelpiece above the grate was a pair of bright red baby shoes neatly placed side by side. My thoughts flew for a moment to my two-year-old daughter Hanka back home with her mother on the farm Anyskop, Moorreesburg. Should I take them back as a souvenir from Italy? I knew immediately it was an unworthy thought and I put it from my mind.

Then as I moved forward I saw on the floor behind the table the head of a woman with long grey hair. She was stretched flat on her back with a bullet hole between the eyes. As I moved round the top of the table to get a closer look, I caught a glimpse of a jumble of women's clothing in the corner behind the open door.

Huddled in a heap were four young women, the one nearest me clutching to her body as if to shield it from evildoers from whom there was no escape, a baby of about two years - the owner of the two little red shoes.

The bodies were all frozen hard with the exposed portions of skin stretched like parchment over the bones of faces and hands.

I called to my companions outside to come in and have a look. No one said a word. What was there to say? The five women and the baby had been sitting down to supper, their menfolk who knows where? Tending the cattle in the barn or more likely attending a meeting in the vicinity as members or supporters of the Red Star Partisan Brigade? Then the sound of jackboots on the 
flagstones outside, the door kicked open and the SS storm troopers crowding in, Schmeisser machine pistols in their hands, evil grins on their faces and their eyes cold and hard like those of beasts of prey about to pounce.

That it was all over within a matter of minutes was evidenced by the fact that contents of the room were undisturbed. They came only to kill. Or had grandmother on the other side of the table jumped to her feet and defied the order to join the others outside who were being marched to line up at the water furrow? And then receiving that bullet between the eyes in reply? And the four younger ones then pushing back their chairs and bunching together in the corner in terrified anticipation of the bursts of fire which sent the heavy leaden slugs ripping through their bodies? Who knows? The two little red shoes on the mantelpiece were the only witnesses to the horror of those moments before the Nazi murderers stomped out into the night, and they could'nt talk. I looked at them again before I left, but I did take with me a walking stick hanging behind the door as another mute witness to the scene that haunts me still.

A review of Col. Olsen's book in 'The Yorkshire Post' summed it up. 'To read this brilliant documentary is an emotional experience that makes one feel such savagery could not really have happened. Yet it did. . . it becomes heart-rending to experience, by means of Olsen's vivid, relentless pen, the horrors wreaked when the SS came to the mountain of the sun. ... The butchery was repeated at every farm and village. And priests were not spared. . Pregnant women were shot down, their unborn children ripped from them and hurled aside. Children were impaled on spikes in orchards. Others, wounded, lived in dread of the coup de grace. And when the unspeakable rites of the SS were over no birds sang on Monte Sole.'

In a foreword, the author of 'Silence on Monte Sole' writes: 'Even though it may often seem so, this is not a book about German evil and Italian innocence. This is a book about the effects of war. There are no heroes and no villains. So long as there are wars, there will be massacres like Monte Sole and corruptible human beings, of all races, willing to carry them out.'
Major Reder, the one-armed veteran of the campaign against the Russians on Germany's Eastern Front before his unit was transferred to Italy, wrote to the Mayor of Marzabotto on 30 April 1967 to plead for a referendum of the survivors of the 'mournful deeds committed in Marzabotto' to grant him a pardon. He submitted that 'those who gave the orders which brought about such odious deeds have been free for many years now, for example Field Marshal Kesselring, sentenced to death.' The reply sent to Reder after the referendum was duly held, read in part as follows: 'It was not an act of war that was committed here, as Kesselring said, but a horrendous massacre, an inhuman reprisal against unarmed peoples, an act of cowardliness and of hatred and nothing else. For this reason, a pardon is unthinkable.'

\section{P.S.}

Things have changed in the 30 years and more since the victorious Allies hanged Herman Goering and some of his cronies at Nuremberg after their conviction on charges of having committed various kinds of war crimes. Although there have been plenty of wars fought since those days, no one has been put on trial for war crimes. This despite the fact that in Africa, and in every other Continent for that matter, people in the guise of 'freedom fighters' are still bayonetting babies, mutilating, burning and raping innocent women and torturing and killing their menfolk. These are the people who are nowadays feted by the United Nations and fawned upon by Kings and Queens, Presidents, Prime Ministers and Prelates.

What the difference might be between these latter-day champions of 'human rights' and a monster like Reder, eludes one. If you were to hazard a guess, you are sure to be branded an imperialist-colonialist-capitalist-racist warmonger.

\footnotetext{
A journalist by profession and an official war correspondent with the 6th SA Armoured Division in Italy. Maior Biermann was on the Reserve of Officers from 1945 until 1976, when he was appointed in the Directorate of Personnel Procurement, Chief of Staff Personnel, to produce recruiting publicity. He retired on August 31, 1981. Hon. Life Member, Royal Natal Carbineers Association and member and hon. member of other South African, American, German and Canadian military veterans' organisations.
} 